\title{
ORAL HEALTH OF BUILDING CONSTRUCTION WORKERS: AN EPIDEMIOLOGICAL APPROACH
}

\author{
SAÚDE BUCAL DE TRABALHADORES DA CONSTRUÇÃO CIVIL: \\ ABORDAGEM EPIDEMIOLÓGICA
}

\begin{abstract}
Nilce Emy TOMITA ${ }^{1}$ Luiz Eduardo Montenegro CHINELLATO ${ }^{2}$, José Roberto Pereira LAURIS ${ }^{1}$, Cláudia Minami KUSSANO ${ }^{3}$, Haroldo José MENDES ${ }^{4}$, Maria Teresa Valente CARDOSO ${ }^{5}$
\end{abstract}

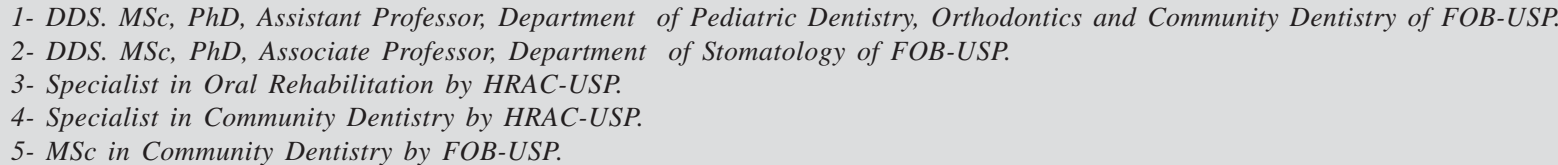

Corresponding address: Nilce Emy Tomita - Faculdade de Odontologia de Bauru - USP - Departamento de Odontopediatria, Ortodontia e Saúde Coletiva - Alameda Dr. Octávio Pinheiro Brisolla, 9-75 - Vila Universitária - Cep.: 17012-901 - Bauru - SP - E-mail: netomita@usp.br

Received: December 5, 2003 - Modification: March 5, 2004 - Accepted: October 6, 2004

\begin{abstract}
$T_{\text {his }}$ utilized the functional number of each worker as a criterion to the raffle, which took into account all 450 subjects registered in the Working Accidents Prevention Program. The examination of oral health conditions by DMFT index and need of treatment were carried out according to WHO criteria (1997). This paper reports the prevalence of caries according to age, occupation, and educational level. Among the 219 workers examined, the mean DMFT was 16.9. Amongst the younger workers ( $<25$ yearsold), 21.3 teeth showed no need of treatment, while the older ones showed increasing treatment needs $(\mathrm{p}<0.001)$. The DMFT values were 15.6 for the administrative duties and 21.7 for foremen and bricklayers, although the differences were not statistically significant. The DMFT index showed an increase with age for all groups $(\mathrm{p}<0.001)$. The self-reported need of treatment was associated with a smaller DMFT for people that reported a positive response when compared with subjects that did not report these needs $(\mathrm{p}<0.05)$. These differences were statistically significant, as tested by ANOVA and Student $t$ test. Among the building construction workers, in this study, important oral lesions were not observed, despite the daily exposition to some risk factors for oral cancer.

Uniterms: Oral health; Worker health; Epidemiology; Dental caries.
\end{abstract}

\begin{abstract}
RESUMO
$E$ ste estudo transversal foi delineado para avaliar as condições de saúde bucal de trabalhadores da construção civil em município da região centro-oeste do Estado de São Paulo. Foram examinados 219 indivíduos do sexo masculino, com idades entre 17 e 72 anos. O levantamento das condições bucais foi realizado em processo de amostragem aleatória simples, a partir do total de 450 inscritos na MEGA-SIPAT 2000 (Semana Interna de Prevenção de Acidentes do Trabalho). Foi utilizado o índice CPOD (cárie dentária) e necessidade de tratamento odontológico, segundo metodologia proposta pela Organização Mundial da Saúde (1997). Neste estudo, são descritas a prevalência de cárie segundo a idade, ocupação e escolaridade. Entre os 219 trabalhadores examinados, o valor CPOD apurado foi 16,9. Os trabalhadores mais jovens ( $<25$ anos de idade) apresentaram média de 21,3 dentes sem necessidade de tratamento, enquanto os mais velhos mostraram necessidades progressivas de tratamento restaurador e reabilitador ( $<<0,001)$. Verificou-se índice CPOD de 15,6 para os trabalhadores de áreas administrativas e 21,7 para os mestres-de-obras, sem significância estatística. Houve aumento do índice CPOD segundo a idade, para todos os grupos de trabalhadores $(\mathrm{p}<0,001)$. A necessidade de tratamento auto-referida mostrou-se associada a valores CPOD mais baixos para os indivíduos que relataram resposta positiva, quando comparado àqueles que não apresentavam percepção de tais necessidades $(p<0,05)$. Estas diferenças foram significantes, à análise de variância e teste $t$ de Student. Para os trabalhadores da construção civil, neste estudo, não foram observadas lesões orais importantes, presentes em apenas 2,7\% dos indivíduos, apesar da exposição diária a alguns fatores de risco para câncer de boca.

Unitermos: Saúde bucal; Saúde do trabalhador; Epidemiologia; Cárie dentária.
\end{abstract}




\section{INTRODUCTION}

There are some studies about the association between occupational exposure and greater incidence of oral diseases. Some examples are the relation between oral diseases and work in cement industry ${ }^{5}$, petrochemical industry $^{1,9,18}$ agriculture $^{4,8,10}$, and, particularly, work in food industry ${ }^{13,15,17}$. In some countries like Germany, the causeeffect relationship between occupational exposure and morbidity is guaranteed by labor law. The occurrence of dental caries in the buccal surfaces in bakery workers is sufficient to characterize an occupational disease ${ }^{15}$.

It is important to know the oral diseases affecting workers, as well as to study the impact of these diseases on their life quality ${ }^{2}$, giving evidence to the causality of oral diseases and its distribution among populations.

It is necessary to consider the ignorance of employees about their real oral condition and the urgent need of an efficient policy for workers' health ${ }^{1}$.

Agricultural workers show one of the worst socioeconomic statuses in society and also have a high prevalence of caries and periodontal disease ${ }^{10}$. In some surveys, it was observed that some risk factors for oral diseases in workers are age, educational level, smoking habits and general health status $^{8,10}$.

The propositions of this study were to evaluate the oral health conditions of building construction workers in Bauru, Brazil; to assess the prevalence of dental caries, oral lesions and oral treatment needs in this population; and to evaluate the association between some socio-economic variables, the self-reported oral health conditions and the epidemiological condition.

\section{MATERIALAND METHOD}

Two hundred and nineteen workers, of male gender, in activity at building construction in Bauru, Brazil, were submitted to an oral examination, in order to evaluate the prevalence of dental caries. This sample was randomized and the employees were sorted out from a list of 450 inscriptions to the "Week of Labor Accidents Prevention", which occurred in October, 2000. A random table was used to raffle $50 \%$ of workers. There were 6 refusals to participate in this survey. Then, the sample was comprised by 219 subjects.

The oral examinations took place in beds, during the event. Three dentists were previously calibrated to perform that epidemiological conduct. They utilized oral mirrors and periodontal probes to verify the presence of dental caries, according to the World Health Organization ${ }^{19}$ (1997) methodology. In order to guarantee the reliability of results, a reexamination of $10 \%$ of subjects was performed.

The Kappa test revealed an agreement of $96.2 \%(\mathrm{k}=0.93)$ for crown condition; 92.4\% ( $\mathrm{k}=0.87)$ for root condition; and $89.4 \%(\mathrm{k}=0.84)$ for dental treatment needs.

Furthermore, an assessment of socio-economic factors was performed, using an adapted questionnaire ${ }^{3}$. Some social factors wer addressed, as actual function, work time, anterior function, family income, educational level, medical care, smoking, dental care, diet, self-care and prosthesis use.

This study was submitted to the Ethics Committee of Bauru Dental School, according to the National Health Council - Resolution 196/96.

Data were processed using the Statistica for Windows software, using Student t test and analysis of variance, in order to test some associations between occupational conditions and oral health. For all tests, a significance level of 0.05 was adopted.

\section{RESULTS}

The participants comprising this sample were divided according to age range, being groups of 25-34 and 35-44 years old (Table 1 ) greater in number.

As age increased, there was a significant increase in the DMFT index (Figure 1).

Caries history according to occupation presents smaller values among workers of administrative functions. In general, workers involved in manual professions presented a more elevated DMFT index, except for tow-car operators (Figure 2).

Caries history is reduced as schooling increases (Figure 3). Taking schooling into account as an important indicator of access to consumption goods highly associated with other socio-economical variables, such finding shows that the educational level inferior to the $8^{\text {th }}$ grade of elementary school seems to constitute a cut-line, under which caries index is significantly higher.

Age increase brings forth a significant increase in the need of some modality of dental treatment. Figure 4 demonstrates the number of teeth that did not present treatment needs, according to age group. Particularly among the youngest, there was a greater mean number of teeth in sound conditions.

TABLE 1- Sample distribution according to age group. Bauru, Brazil, 2001

\begin{tabular}{|c|c|c|c|c|c|c|c|c|c|}
\hline \multicolumn{10}{|c|}{ AGE GROUP } \\
\hline \multicolumn{2}{|c|}{$<25$} & \multicolumn{2}{|c|}{$25-34$} & \multicolumn{2}{|c|}{$35-44$} & \multicolumn{2}{|c|}{$45-54$} & \multicolumn{2}{|c|}{$>54$} \\
\hline $\mathrm{N}$ & $\%$ & $\mathrm{~N}$ & $\%$ & $\mathrm{~N}$ & $\%$ & $\mathrm{~N}$ & $\%$ & $\mathrm{~N}$ & $\%$ \\
\hline 30 & 13.7 & 65 & 29.7 & 67 & 30.6 & 32 & 14.6 & 25 & 11.4 \\
\hline
\end{tabular}


By confirming findings in the literature ${ }^{18}$, it is observed that those individuals who report dental treatment needs present a significantly smaller DMFT index as compared to those who do not consider to be in need of any sort of treatment (Figure 5). This might be explained by a greater awareness of oral health care, leading to an earlier search of health services.

\section{DISCUSSION}

The sample was comprised of male individuals and this age composition contemplates mainly the period considered as productive, reflecting the scenario existing in the work market for professionals of low and medium skills (Table 1).

The lower caries prevalence for the group evaluated in the present study (Figure 1) when compared to state indicators might be attributed to differences in sample

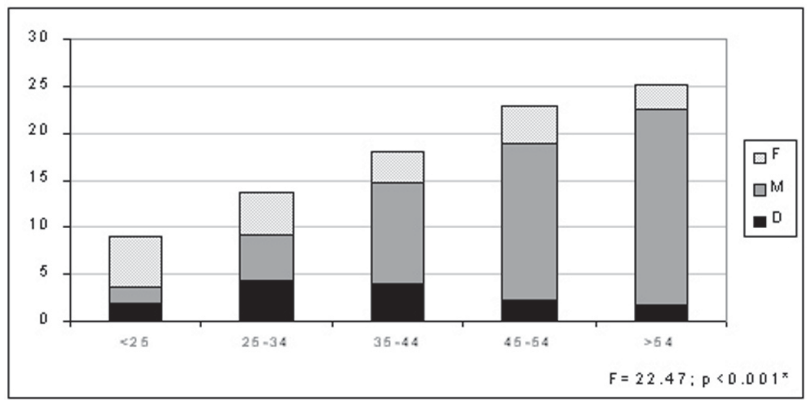

FIGURE 1- Prevalence of dental caries (DMFT) according to age group (years). Bauru, Brazil, 2001

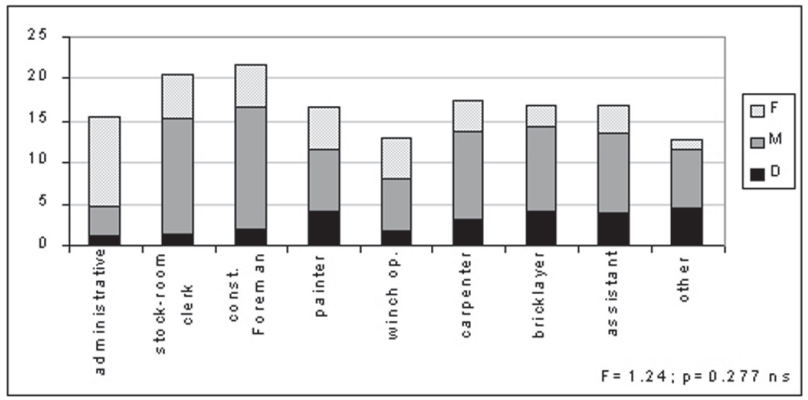

FIGURE 2- Prevalence of dental caries (DMFT) according to occupation. Bauru, Brazil, 2001

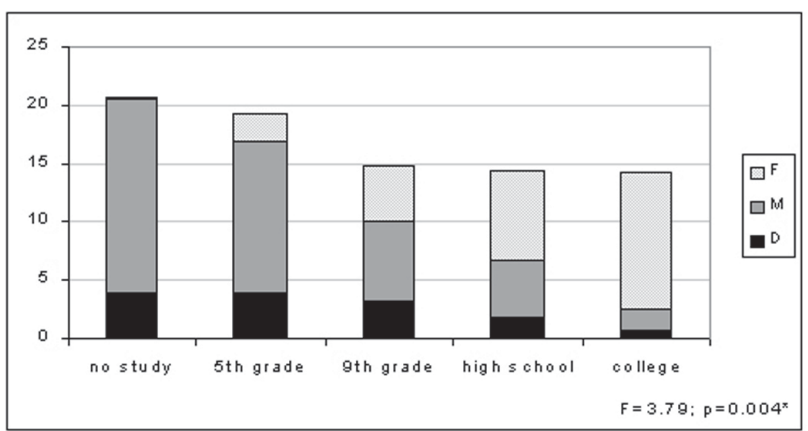

FIGURE 3- Prevalence of dental caries (DMFT) according to educational level. Bauru, Brazil, 2001 composition, once some studies used school employees as target population for epidemiological evaluation ${ }^{11}$.

Nevertheless, the termed "healthy worker effect"7 may, in some situations, explain important differences in health conditions of individuals that are inserted in the work market. Despite the exposure to some risk factors for oral diseases, like solar radiation, only 6 subjects $(2.7 \%)$ presented oral lesions. Complementary diagnosis identified stomatitis, lip hemangioma, aphthae and hiperqueratosis.

At the index age range of 35-44 years, a DMFT of about 18.0 was verified, which is the average for the mid-west region of São Paulo; the mean for Brazil is 23.1, and for the State it is $21.0^{11}$.

Frequently, the access to work is accompanied by indirect benefits, such as dental-medical assistance. Along with the wear process deriving from the work process and the exposure to risks, one observes that the generation of an income allows the worker (and his family) to have a more satisfactory health condition than non-workers. Besides, the access to dental attendance allowed by health plans or union attendance appears to provide the worker with an oral health standard in which a smaller caries history/or dental losses are observed.

There are strong scientific evidences of a positive association between socio-economic status and health. This relation has been verified in several surveys, regardless of the socio-economic indicator used ${ }^{6,11,12,14,17}$.

The relation between social class and health has also been observed under an oral health perspective. Individually, there are evidences that corroborate the correlation between

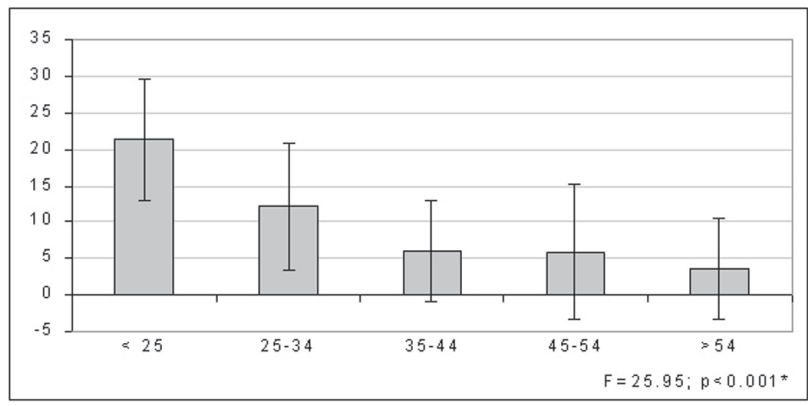

FIGURE 4- Sample distribution according to mean (sd) number of teeth presenting no dental treatment needs. Bauru, Brazil, 2001

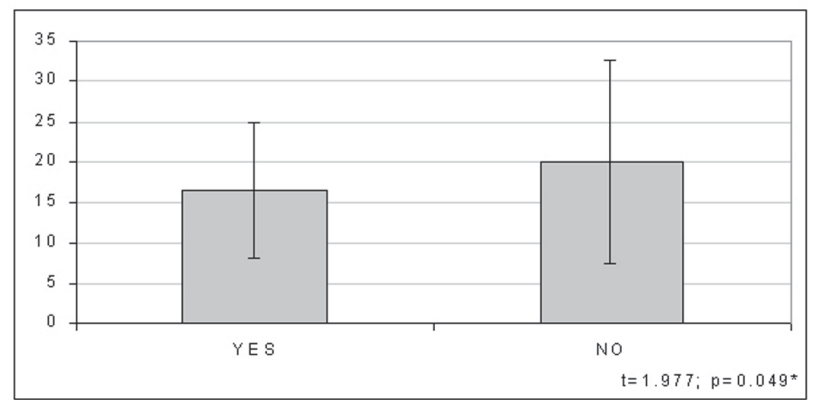

FIGURE 5- Prevalence of dental caries (DMFT and standard deviation) according to self-reported dental treatment needs. Bauru, Brazil, 2001 
social class, dental caries and periodontal disease ${ }^{12}$. In the present study, when comparing the DMFT index among workers with diversified occupational insertions, it is verified that caries history most deeply involves some kind of manual workers, like construction foremen and carpenters than those dealing with administrative functions, although no statistically differences were observed (Figure 2).

Schooling and occupation are strongly related. Even though the current society faces the global hardships of unemployment, the relation between the access to levels of education and the corresponding work position is generally maintained, so that non-manual workers are the ones who present skills on technical and higher education levels. Subjects with no access to formal education or those who precociously interrupted their studies to join the work force are given functions that require a lower qualification. As a result of this equation, oral health conditions reflect that the higher the schooling, the lower the caries prevalence (Figure 3). As for edentulism, low schooling was reported as one of risk factors in populations with a productive age ${ }^{10}$, and dental extractions as a therapeutic measure owing to caries and periodontal disease may be observed in populations of lower social-economic levels ${ }^{12}$.

In adulthood, there is an abrupt reduction of mean values of tooth presenting no dental treatments need. It is supposed that the evolution of caries history and consequent increment in the DMFT index may be attributed to the loss of dental elements through extractions or periodontal disease (Figure 4).

Thus, the oral health situation of workers in Brazil indicates precariousness, associated with a reduced access to dental assistance ${ }^{12,14}$. The reflexes of absence of health policies contemplating the workers ${ }^{\prime}$ oral health ${ }^{1}$, along with the financial difficulties of the national scenario may be seen in the described epidemiological picture.

Paradoxically, the objective condition is more satisfactory among individuals with a more critical point of view about their oral health and respective treatment needs than among those who presented a little accurate perception of these needs (Figure 5). It is just appropriate to highlight that selfperception does not always find correspondence in the normative evaluation.

Nevertheless, they might constitute complementary readings for the unveiling of diagnosis, referral, guidance and joint search for solutions at the amplitude of oral problems presented by the adult segment inserted in the work world.

\section{CONCLUSION}

In face of the results obtained, it was concluded that building construction workers present high caries prevalence, which decrease with the increase in educational level. Despite the exposure to some risk factors for oral cancer, a few number of workers presented oral lesions, although this situation must be viewed under the agenda of public health politics.

\section{REFERENCES}

1- Araújo ME, Marcucci G. Estudo da prevalência das manifestações bucais decorrentes de agentes químicos no processo de galvanoplastia: sua importância para a área de saúde bucal do trabalhador. Odontologia e Sociedade 2000;2:20-5.

2- Bergström J, Eliasson S. Dental care habits, oral hygiene, and gingival health in Swedish professional musicians. Acta Odontol Scand 1985;43:191-7.

3- Barros FC, Victora CG. Epidemiologia da saúde infantil: um manual para diagnósticos comunitários. São Paulo, HUCITEC/UNICEF; 1991.

4- Blignaut JB, Grobler SR. High fruit consumption and the periodontal status of farm workers. Clin Prevent Dent 1992;14(2):25-7.

5- Bozyk A, Owczarek B. Incidence of parodontal diseases in workers of the Chelm Cement Plant exposed to cement dust. Czasopismo Stomatologiczne 1990;43(6): 375-80.

6- Brasil, Ministério da Saúde. Divisão Nacional de Saúde Bucal. Levantamento epidemiológico em saúde bucal - Brasil, Zona Urbana, 1986. Brasília, Centro de Documentação do Ministério da Saúde; 1988.

7- Chen R, Seaton A. The influence of study characteristics on the healthy worker effect: a multiple regression analysis. Occupational medicine 1996;46(5):345-50.

8- Dini EL, Guimarães LO. Periodontal conditions and treatment needs (CPITN) in a worker population in Araraquara, SP, Brasil. Int Dent J 1994;44(4):309-11.

9- Duffy B. Dental problems in the offshore oil and gas industry: a review. Occupational medicine 1996;46(1):79-83.

10- Gangarosa LP. Oral Health care for migrant agricultural workers in Monroe county, New York. N Y State Dent Assoc 1968;34(8):481-4.

11- Levantamento Epidemiológico em Saúde Bucal: Estado de São Paulo, 1998. São Paulo, Faculdade de Saúde Pública-USP/ Secretaria de Estado da Saúde de São Paulo, 1999.

12- Marcenes W, Bönecker MJS. Aspectos epidemiológicos e sociais das doenças bucais. In: Buischi YP. Promoção de saúde bucal na clínica odontológica. São Paulo, Artes médicas/EAP-APCD; 2000. p.73-98

13- Masalin K, Murtomaa H, Muerman JH. Oral health of workers in the modern Finnish confectionery industry. Community Dent Oral Epidem 1990;18(3):126-30.

14- Pinto VG. Saúde bucal coletiva. 4. ed. São Paulo, Ed. Santos; 2000. p.223-50, 346-7.

15- Sonnamend E, Maschinski G, Sussmann G. Investigation of baker's caries in bakery and confectionary students. Zahnarztliche welt, zahnarztliche rundschau, zahnarztliche reform, das deutsche zahnarzteblatt. Stoma 1991;100(3):171-3.

16- Suominen-Taipale AL, Alanen P, Helenius H, Nordblad A, Uutela A. Edentulism among Finnish adults of working age, 1978 - 1997. Community Dent Oral Epidem 1999; 27:353- 65.

17- Tomita NE, Cordeiro R, Mendonça J, Senger V, Lopes ES. Saúde bucal dos trabalhadores de uma indústria alimentícia do centro-oeste paulista. Rev FOB 1999;7:67-91.

18- Werckmeister J, Ruppe K. Prevalence of damages of dental, the oral and the jaw areas among workers exposed to substances in a chemical company. Stomatologie der DDR 1990; 40(4):172-4.

19- World Health Organization. Oral health surveys: basic methods. $4^{\text {th }}$ ed. Geneva: ORH/EPID; 1997. 